Nisfet Kovačević, prof. ${ }^{1}$

\title{
PRIMJERENOST NASTAVNIH SADRŽAJA ,ISLAMSKE VJERONAUKE“" UZRASTU UČENIKA PRVOG I DRUGOG RAZREDA OSNOVNE ŠKOLE
}

\section{Sažetak}

Stalno nastojanje sudionika nastavnog procesa je da djeci na primjeren način prezentuju i dostave gradivo predviđeno nastavnim planom i programom. Udžbenik je nezaobilazno sredstvo u realizaciji tog zadatka. Zato je cilj ovog rada bio osvrt na primjerene $i$ neprimjerene sadržaje uzrastu učenika, u udžbenicima Vjeronauke I $i$ II za osnovnu školu, te da se ispita dominacija jednog nad drugim.

$U$ radu se, kroz teorijsku analizu, anketno istraživanje $i$ sakupljanje $i$ obradu podataka potvrdila hipoteza da je u oba udžbenika znatna dominacija primjerenog nad neprimjerenim nastavnim sadržajem. Isto tako, posebno su naglašeni i konkretizovani primjeri neprimjerenog nastavnog sadržaja uzrastu učenika prvog $i$ drugog razreda osnovne škole, a samo istraživanje ukazalo je i na potrebu veće međupredmetne korelacije tokom planiranja. Samim tim ovaj rad je poticaj daljem istraživanju u cilju što kvalitetnije izrade udžbenika, planiranja i realizacije nastave.

Ključne riječi: islamska vjeronauka, nastavni plan i program, učenik, udžbenik vjeronauke, školsko gradivo.

\section{Uvod}

Odabir teme ovog rada motiviran je činjenicom da se kroz praksu pokazalo postojanje određenog gradiva u udžbenicima Islamske vjeronauke za prvi i drugi razred osnovne škole, koji je primjeren uzrastu učenika, ali, također, i dijela gradiva koji nije primjeren. Radeći kao nastavnik, kroz vlastitu praksu, sam to zapazio. Namjera mi je da ovim radom skrenem pažnju na gradivo koje je primjereno uzrastu učenika, ali i na ono koje nije primjereno.

\footnotetext{
${ }^{1}$ Student II ciklusa studija na Islamskom pedagoškom fakultetu u Bihaću
} 
Znajući da se udžbenici rade na osnovu nastavnog plana i programa ovo nije negativna kritika autoru udžbenika, već je cilj ovog rada ukazati na one sadržaje koji su primjereni određenom uzrastu i koje treba naglašavati, a zatim treba ukazati na neprimjerene sadržaje, kako bi se ti nedostaci ispravili, imajući u vidu koje kognitivne sposobnosti imaju učenici prvog i drugog razreda osnovne škole.

U ovom radu posebna pažnja će biti usmjerena na to da li su udžbenici vjeronauke za prvi i drugi razred, koji su zasnovani na $\mathrm{NPP}^{2}$, prilagođeni učenicima da usvoje, zadrže i koriste informacije na njima primjeren način. Radi boljeg uvida u problematiku navest ćemo definiciju učenja koja se uglavnom ponavlja kod većine autora, a koja glasi: "Ljudsko učenje, u većini svojih oblika, proces je svjesnog i aktivnog stjecanja i zadržavanja znanja, vještina i navika." (Enciklopedijski rječnik pedagogije, 1963:1050). Na osnovu ove definicije možemo vidjeti da učenje nije samo verbalno usvajanje gradiva, već mnogo širi i kompleksniji pojam. Možemo još navesti definiciju pojma pamćenje, jer je taj pojam usko vezan za učenje: "Pamćenje određujemo kao mogućnost usvajanja, zadržavanja i korištenja informacija." (Zadevski, 1997:27)

Također, pored učenja i pamćenja, treba voditi računa o mogućnostima i načinu ponavljanja i ispitivanja usvojenog gradiva. Što se tiče razumijevanja gradiva kod učenika, ono uglavnom zavisi od uzrasta, ali i od ličnog stepena inteligencije. Dalje, zaključivanje kod djece je vezano za inteligenciju, ali i za sposobnost koju djeca $\mathrm{u}$ toku učenja razvijaju. Bitan faktor na koji treba obratiti pažnju kod kognitivnih mogućnosti učenika jeste reprodukcija. Reprodukcija može biti verbalna i neverbalna.

Pored gore navedenog, udžbenik treba da njeguje unutrašnje duhovne i vanjske - fizičke potrebe učenika i veoma važno, prilagođenost uzrastu.

\footnotetext{
${ }^{2}$ Nastavni plan i program
} 


\section{Spoznajne (kognitivne) mogućnosti djece prvog i drugog razreda osnovne škole}

Važno je naglasiti da svaki udžbenik vjeronauke treba da ima za cilj poboljšanje pozitivnih osobina kod učenika ili poboljšanje ponašanja. Sa stanovišta psihologije je ustaljeno mišljenje da se ponašanje može mijenjati kod ličnosti. Nastavni plan i program, na kome se temelje udžbenici za prvi i drugi razred vjeronauke, bi trebao pozitivno mijenjati ponašanje djece kroz nastavne sadržaje i gradivo jer znamo da je sa strane Šerijata, pored znanja vrlo značajno i islamsko ponašanje.

\subsection{Prvi razred osnovne škole}

$\mathrm{Na}$ početku, odmah, moramo istaknuti da djeca ovog uzrasta uglavnom nemaju mogućnost zaključivanja na osnovu logičkih operacija, već su njihova razmišljanja konkretna i pod uticajem vizualnih dojmova. Period prvog razreda obuhvata, uglavnom, djecu uzrasta od šest godina, djeca tog uzrasta polaze u prvi razred devetogodišnjeg školovanja u našim osnovnim školama. Ovo naravno treba uzeti u obzir prilikom analize udžbenika za prvi razred devetogodišnjeg školovanja. Ova djeca uglavnom mogu učiti pomoću igre i crtanja. Prilikom crtanja djeci je važno da crtaju nešto konkretno.

Djeca, prvog razreda, nisu u mogućnosti izražavati se pismeno putem slova, jer slova uče tek u drugom polugodištu. Sa pozicije pedagogije, ovdje je bitno naglasiti da kod djeteta treba pedagoški djelovati u smjeru razvijanja sposobnosti: uočavanje stvari i pojava u okolini, prepoznavanje, imenovanje, korištenje, zadržavanje pažnje, razvoj pamćenja, zapažanje detalja, razvijanje rječnika, mašte i sl. ${ }^{3}$ Bitno je da dijete usvoji osnovne sposobnosti koje su potrebne za dalji rad, a to su korištenje sredstava u nastavi, korištenje udžbenika i sveski, lična higijena i sl. Ovaj je podatak presudan kod procjene pedagoške primjerenosti sadržaja udžbenika islamske vjeronauke prvog razreda uzrastu učenika. Ako je sadržaj u funkciji razvijanja ovih sposobnosti onda je primjeren.

\footnotetext{
${ }^{3}$ V.: Malić i Mužić, 1984:205.
} 
Gradivo u udžbenicima islamske vjeronauke prvog razreda trebalo bi omogućiti djeci da zadrže dovoljno pažnje na određenom gradivu. Dijete nije u mogućnosti dugo zadržati pažnju. Ovaj podatak je bitan kod izrade sadržaja, ali je bitan i za nastavnika. Treba naglasiti da se na ovom uzrastu izbjegavaju duge pjesmice, odnosno tekstovi dužeg sadržaja.

Kad je u pitanju sama artikulacija časa, gradivo se ne može obrađivati klasičnim obrascem: uvod, glavni dio i završni dio, već mora da uvaži kreativni rad samog učenika. Ovo poglavlje treba da posluži kao osnova za izučavanje gradiva u udžbenicima prvog razreda u smislu primjerenosti sadržaja tom uzrastu, ne samo islamske vjeronauke, već i drugih predmeta, koji se izučavaju u prvom razredu.

\subsection{Drugi razred osnovne škole}

Moramo imati u vidu da djeca i ovog uzrasta uglavnom nemaju mogućnost zaključivanja na osnovu logičkih operacija, već su njihova razmišljanja konkretna i pod uticajem vizualnih dojmova. Period drugog razreda obuhvata djecu uzrasta od sedam godina. Ovo naravno treba uzeti $\mathrm{u}$ obzir prilikom analize udžbenika za drugi razred devetogodišnjeg školovanja. Ova djeca kao i djeca prvog razreda uglavnom mogu učiti pomoću igre i crtanja. Iako su djeca ovog uzrasta već u prvom razredu savladala štampana slova, tako da gradivo za njih može postepeno prelaziti i na pismeno izražavanje putem slova.

Njihove mogućnosti učenja su povećane. Tako da mogu da usvoje malo duže tekstualne sadržaje u obliku pjesmica i recitacija. Djeca se i u ovom periodu vole izražavati crtežom, mada njihov crtež nije puno napredniji od ranijeg uzrasta.

Udžbenik islamske vjeronauke će uspjeti ako ponudi bliske sadržaje svijetu sedmogodišnjaka i ukoliko to učini na način koji djeca prepoznaju. Sadržaj udžbenika treba da pruži i motivira nastavnika na ovakav vid artikulacije časa. Gradivo ne treba da je nametljivo i grubo. Što se tiče pedagoške strane, udžbenik treba da pruža one činjenice i sadržaje koje će ići u korist formiranja zdrave ličnosti. Znamo da je period školskog doba važan za formiranje zdrave ličnosti svakog pojedinca. Upravo ovaj i drugi faktori i činjenice treba da su 
smjernice i upute kod izrade udžbenika islamske vjeronauke za drugi razred, jer kad govorimo o razvoju ličnosti svaki period je značajan, ali znamo da se dijete počinje socijalizirati i usvajati društvene norme upravo kroz školovanje.

\section{Primjerenost nastavnog sadržaja islamske vjeronauke prvog razreda uzrastu učenika}

Predmet proučavanja u ovom radu je udžbenik Islamske vjeronauke za prvi razred osnovne škole: BEGOVIĆ, Ibrahim, Vjeronauka za prvi razred osnovne škole/ Ibrahim Begović; (ilustracija Edin Alić). Sarajevo: El-Kalem, 2005.-72 str.: ilustr.; 26 cm.

Prije svega treba naglasiti da je vjeronauka u Bosni i Hercegovini uvedena u škole 1990. godine. Prvi udžbenici za vjeronauku su urađeni 1996. godine i bez obzira na niz nedostataka, uveliko su pomogli vjeroučiteljima, koji su tada predavali, ${ }^{4} \mathrm{u}$ realizaciji nastavnih sadržaja. Ti udžbenici su doživjeli reviziju, te su se prelaskom na devetogodišnje školovanje u Bosni i Hercegovini od 2005. godine počeli zamjenjivati novim udžbenicima vjeronauke, svake godine po jedan udžbenik. Tako je 2005. godine izašao novi udžbenik za prvi razred devetogodišnjeg školovanja koji je do sada već prošao jednu reviziju.

Ovaj udžbenik, Vjeronauka 1, kako ga autor naziva, u potpunosti prati Nastavni plan i program Islamske vjeronauke za prvi razred. U nastavnom programu vjeronauke navode se nazivi nastavnih jedinica sa osnovnim smjernicama, a autor je na osnovu programa i smjernica izradio udžbenik. Tako da je primjerenost programskih sadržaja analizirana na osnovu analize udžbenika.

Ovaj udžbenik je novijeg izdanja i prilagođen je devetogodišnjem školovanju. Poznato je da djeca na ovom uzrastu uče kroz igru i crtanje. Upravo sadržaji kroz nastavne jedinice: „Pozdravselam “, „Ramazan i ja“, „Kur'an“, „Moj iftar“, ,Ramazanski bajram“" i sl., učenicima pružaju mogućnost da kroz igru nauče ove

\footnotetext{
${ }^{4} \mathrm{U}$ najvećem slučaju vjeronauku su predavali u osnovnim školama, po odobrenju Rijaseta Islamske zajednice u Bosni i Hercegovini, mjesni imami-muallimi gdje se nalazila ta škola.
} 
sadržaje, a također kroz crtanje pokažu svoja umijeća. Na osnovu umijeća crtanja, nastavnik može procijeniti učenikove sposobnosti. Ovim nastavnim jedinicama u obradi dominira crtanje kao aktivnost učenika, što je primjeren način na koji učenici ovog uzrasta mogu usvojiti gradivo, pa i pokazati sposobnosti i vještine radi same evaluacije.

Neki sadržaji, kao što su nastavne jedinice u Vjeronauci za prvi razred: „Džamija“, „,Moja porodica“, „, Svakodnevna lična higijena“, „Moje zdravlje“, „Ljepote prirode“, „Ramazan $i$ ja“ i dr. su usmjereni ka razvijanju djetetovih spoznajnih sposobnosti, kao što su: uočavanje stvari i pojava u okolini, prepoznavanje, imenovanje, razvijanje mašte i sl.

Osnovne sposobnosti za održavanje lične higijene djeca ovog uzrasta mogu savladati kroz sadržaje vezane za higijenu. Na stranici 38., Vjeronauke 1, imamo nastavnu jedinicu koja glasi 'Ljepota prirode". Ovdje je djeci na primjeren način pružena prilika da iskoriste svoje sposobnosti prepoznavanja i imenovanja, jer trebaju na stranici 39. imenovati životinje koje vide na slici. Pored navedenog i većina ostalih sadržaja Vjeronauke 1 je primjeren ovom uzrastu.

Kad su u pitanju neprimjereni sadržaji treba istaknuti da ima i takvih: na 5. stranici Vjeronauke 1 stoji da učenik treba napisati svoje ime na određenu liniju. To ne bi bilo problem da Nastavnim planom i programom za prvi razred nije predviđeno da se slova obrađuju tek $\mathrm{u}$ drugom polugodištu. Tako da se pretpostavlja da većina učenika ne zna napisati svoje ime. Ostaje na nastavniku da napiše ime svakom učeniku koji ne zna pisati, a to svakako izaziva nelagodu ili osjećaj manje vrijednosti kod učenika koji ne znaju pisati.

Tako na stranici 22. Vjeronauke 1 u nastavnoj jedinici „Učim euzubillu" se spominje šejtan kao zlo biće. Prvo što je to za djecu apstraktan pojam koji ne mogu razumjeti, drugo što taj pojam zla bića nije primjeren uzrastu djece od šest godina. Njima trebaju lijepe priče kako bi se emotivno razvili u zdravu ličnost, bez nekih fobija i strahova od okoline. Ne trebaju im u toj dobi znanja o nekim zlim bićima koja su stalno uz njih i tjeraju ih na zlo. Mišljenja sam da se riječ šejtan treba spomenuti na tom nivou apstraktnog radi samog usvajanja pojma, bez riječi ,zlo biće“, dakle na nivou uopštenosti 
Ili na stranici 56. Vjeronauke 1 u nastavnoj jedinici „Allahov poslanik Muhammed, aljhis-s-selam “, djeca imaju zadatak da dopune rečenice, a djeca još nisu učila sva slova i ne vladaju s pisanjem da bi mogli adekvatno uraditi taj zadatak. Možda taj zadatak može uraditi samo nekolicina djece koja već imaju neko predznanje u pisanju, ali i o islamu.

Na kraju se može konstatirati da u Vjeronauci 1 je primjereni sadržaj u velikom omjeru nadmašio onaj koji nije primjeren i to je bilo za očekivati kod ovog udžbenika. Ova tvrdnja je potvrđena Upitnikom za nastavnike. U Upitniku je učestvovalo 10 nastavnika koji predaju ovom razredu od kojih je samo jedan nastavnik tvrdio da ima podjednako primjerenog i neprimjerenog sadržaja, dva nastavnika su ustvrdila da su svi sadržaji primjereni uzrastu prvog razreda. Većina nastavnika, odnosno sedam od deset vjeruje da je većina sadržaja prilagođena uzrastu učenika prvom razredu, a svi nastavnici su odbacili pretpostavku da je većina sadržaja neprimjerena uzrastu učenika, što je bilo za očekivati.

\section{Primjerenost nastavnog sadržaja Islamske vjeronauke drugog razreda uzrastu učenika}

Predmet proučavanja u ovom radu je, također, udžbenik Islamske vjeronauke za drugi razred osnovne škole: TINJAK, Muamer. Vjeronauka za drugi razred osnovne škole/ Muamer Tinjak; (ilustracije:Edin Alić). - Sarajevo: El-Kalem, 2006 .-136 str.: ilustr.; $26 \mathrm{~cm}$.

Treba naglasiti da je udžbenik za drugi razred imao svoj put do sada kao i udžbenik za prvi razred, s tim da je ovaj udžbenik za drugi razred izdat 2006. godine. Predmetni udžbenik za drugi razred je također revidiran.

Ovaj udžbenik, Vjeronauka 2, kako ga autor naziva, u potpunosti prati Nastavni plan i program Islamske vjeronauke za drugi razred. U nastavnom programu vjeronauke navode se nazivi nastavnih jedinica sa osnovnim smjernicama, a autor je na osnovu programa $\mathrm{i}$ smjernica izradio udžbenik. Tako da je primjerenost programskih sadržaja analizirana na osnovu analize udžbenika. Na prvi pogled se 
može zaključiti da je udžbenik grafički i ilustrativno dobro osmišljen i urađen.

Sadržaj koji je primjeren ovom uzrastu je u većini i vrijedi istaknuti slijedeće. Vjeronauka 2 je podijeljena u deset poglavlja koji su gotovo neovisni jedni od drugih. U prvom poglavlju koje nosi naslov „Radost ponovnog susreta“, autor navodi sadržaje vezane za to kako su djeca provela raspust. Ova nastavna jedinica je primjerena za početak drugog razreda iz razloga što su prvi put djeca ovog uzrasta imala ljetni raspust. Vjeronauka 2 u sebi sadrži i jedan vid radne sveske, što je velika prednost za učenike, ali i za nastavnike. Nastavnik već u udžbeniku ima osmišljene aktivnosti koje samo treba realizirati. Sve nastavne jedinice iz spomenutog prvog poglavlja udžbenika su uglavnom primjerene ovom uzrastu.

Drugo poglavlje Vjeronauke 2 podstiče učenika na praktičan rad, da pomogne prijatelju u školi kad je to potrebno. Što se tiče praktičnih aktivnosti, sedmo i deseto poglavlje ih sadrži. Ovdje u sedmom poglavlju djeca mogu odmah na času da nauče neku dovu koju mogu učiti za sebe ili za druge. Djeca vole i za njih su primjereni oni sadržaji koji se tiču njih samih, a dova je upravo to. U desetom poglavlju mogu praktično za domaću zadaću da samostalno, ili uz pomoć roditelja urade nešto u dvorištu ili vrtu.

Kroz primjerene sadržaje učenik može u svoje ponašanje da ugradi plemenita svojstva. Tako kroz poglavlje tri, četiri i pet učeniku se upravo pruža ta mogućnost. Učenik u drugom poglavlju koje nosi naslov „Islam je naša vjera“, može na primjeren način usvojiti one vrline koje treba da krase svakog čovjeka. Dijete može kroz četvrto poglavlje, koje govori o prirodi, razviti pozitivne osjećaje za očuvanjem prirode kao Allahovog dara. U petom poglavlju se govori o Muhammedu , a.s. ${ }^{5}$, kao našem uzoru. Zar to nije primjeren sadržaj za izgradnju zdrave ličnosti?

U šestom poglavlju je zastupljen sadržaj vezan za higijenu, i ona na primjeren način kod djece razvija odgojne komponente održavanja lične higijene. Kroz osmo poglavlje koje nosi naslov „Mubarek dani“, učenik može na primjeren način usvojiti gradivo o islamskim praznicima i svečanostima. Kroz deveto poglavlje kod učenika se

${ }^{5}$ Čitaj: alejhisselam 
razvija osjećaj pripadnosti porodici, te on uči koja je njegova uloga $u$ porodici. Sva ova poglavlja na primjeren način pružaju mogućnost emotivnog povezivanja učenika sa sadržajem, ali i sa nastavnikom u razredu.

Kad je riječ o neprimjerenom sadržaju i njega ima u Vjeronauci 2. Na stranici 25. Vjeronauke 2 nalazi se zadatak Razmisli i dopuni: Riječ drugari znači... i Riječ jaran znači....? Na ovo pitanje učenici ne mogu odgovoriti, prvo; jer nemaju prije toga nikakvo objašnjenje na osnovu kojeg bi izvršili usporedbu, drugo; na ovom stadiju razvoja oni još ne mogu komparirati i vršiti apstraktnu poredbu. Bolje bi bilo da je prije toga bila neka priča o dječaku koji je imao drugara i jarana.

Na stranici 65. Vjeronauka 2 postoji zadatak da djeca „Nacrtaju karavanu koja ide kroz pustinju“, a znamo da djeca vole konkretne crteže u tom dobu. Tako da djeca obično u tom zadatku crtaju lik Muhammeda, a.s., što nije pohvalno, da crtaju lik Poslanika a.s., bez obzira što su to djeca, znajući stav Šerijata po pitanju crteža živih bića.

Nastavnici se slažu da su priče o Muhammedu, a.s., u Vjeronauci 2 na stranicama 61. 63. i 66. prepune riječi koje su teško razumljive za ovaj uzrast, npr.: Jesrib, monah, Sirija, prijašnje Objave $i$ sl. Ovi pojmovi su dosta apstraktni i ne mogu se približiti uzrastu kojem pripadaju ova djeca. Sam sadržaj priča je preopširan. Ove priče bi trebalo obraditi u nekim starijim razredima. Postavlja se pitanje svrhe obrade ovih priča u drugom razredu, ako djeca tog uzrasta ne mogu da dođu do pouke priče. Samim tim, priča nema skoro nikakvog uticaja na pobuđivanju njihovih pozitivnih osjećaja prema Poslaniku, a.s.,

Isto tako na stranici 68. Vjeronauke 2 stoji da je Muhammed, a.s., primjer za slijeđenje. Djeca ovog uzrasta nemaju predstavu kako neko ko nije živ može da se slijedi. Oni riječ slijediti ne mogu razumjeti na apstraktan način kao odrasli. Možda da se zamjene riječ slijediti, npr. Slušati njegove upute, ponašati se kako nam je on preporučio i slično...

$\mathrm{Na}$ stranici 76. Vjeronauke 2 je nastavna jedinica kojom bi nastavnik trebao obraditi uzimanje abdesta. Problemi su: prvo što je za ovaj uzrast preteško da nauče redoslijed uzimanja abdesta, nijet na 
arapskom jeziku je težak, a ista se nastavna jedinica ponavlja više puta u udžbenicima vjeronauke viših razreda.

$\mathrm{Na}$ stranici 94. Vjeronauke 2 stoji da djeca trebaju naučiti značenje nekih arapskih riječi koje se spominju kod učenja tespiha. Ovaj zadatak je pretežak za ovaj uzrast, jer oni još ne mogu da shvate i povežu da neke riječi mogu da znače isto, a da se izgovaraju drugačije. Ove riječi tespiha bi trebali učiti napamet, ali bez prevoda.

$\mathrm{Na}$ strani 101. Vjeronauke 2 djeca imaju zadatak da popune: 622 godine, 354 ili 355 dana, a djeca u drugom razredu uče brojeve samo do 20, te u drugom polugodištu se spominju desetice iz Matematike. Ovo je podatak koji nam govori da tokom izrade udžbenika nisu uzeti u obzir korelacijiski odnosi među predmetima vjeronauka i matematika, jer se ne mogu tražiti brojevi za taj uzrast, ako iz Matematike nisu obrađeni, bez obzira koliko mi bili uvjereni da to nije teško za djecu.

Na stranici 105. Vjeronauke 2 imamo zadatak da djeca trebaju znati gotovo sve o noći Kadr. Zašto bi trebali znati da se u toj noći opraštaju manji grijesi, jer njima se ne pišu grijesi. Trebalo bi više sadržaja ove nastavne jedinice posvetiti ljepotama ove noći.

Na stranici 113. Vjeronauke 2 djeca imaju zadatak da nacrtaju mezarje/šehitluke. Nastavnik treba djeci ovog uzrasta pokušati objasniti riječ šehid. Kako? Jer kako djeci objasniti da su to borci na Allahovom, dž.š., ${ }^{6}$ putu. Kako objasniti kakav je to put? Kako izgleda i slično? Podsjećanje djece ovog uzrasta na rat, smrt i pogibije nije poželjno. S obzirom na aktualnosti današnjih nasrtaja medija na islam i vjeronauku, moglo bi se s pravom reći da ovi termini djecu odgajaju u duhu nasilja.

Na kraju se može konstatirati da je u Vjeronauci 2 primjereni sadržaj u velikom omjeru nadmašio onaj koji nije primjeren $i$ to je bilo za očekivati kod ovog udžbenika. Ova tvrdnja je potvrđena Upitnikom za nastavnike. U Upitniku je učestvovalo 10 nastavnika koji predaju ovom razredu od kojih je samo jedan nastavnik tvrdio da ima podjednako primjerenog i neprimjerenog sadržaja, tri nastavnika su tvrdila da su svi sadržaji primjereni uzrastu prvog razreda. Većina nastavnika, odnosno šest od deset, vjeruje da je većina sadržaja

${ }^{6}$ Čitaj: Džellešanuhu 
prilagođena uzrastu učenika prvom razredu, a svi nastavnici su odbacili pretpostavku da je većina sadržaja neprimjerena uzrastu učenika, što je bilo za očekivati.

\section{Akcijsko istraživanje}

\subsection{Problem istraživanja}

Naredni dio rada predstavlja završna razmatranja provedenog istraživanja - analizu, obradu i prezentaciju dobivenih rezultata. Uloga provedenog istraživanja je da se, uz teorijski pregled problematike, akcijskim istraživanjem na terenu dobije uvid situacije u našim školama u domenu primjerenosti nastavnih sadržaja islamske vjeronauke uzrastu učenika prvog i drugu razreda osnovne škole, što predstavlja drugi dio rada.

\subsection{Cilj istraživanja}

Glavni cilj ovog istraživanja je utvrditi u kojoj mjeri su sadržaji udžbenika za prvi i drugi razred islamske vjeronauke primjereni uzrastu učenika.

\subsection{Zadaci istraživanja}

- utvrditi, na osnovu podataka koliko udžbenici za prvi i drugi razred islamske vjeronauke u osnovnoj školi imaju primjerenog sadržaja

- pomoću upitnika, doći do mišljenja nastavnika islamske vjeronauke o tome koliko su nastavni sadržaji islamske vjeronauke za prvi i drugi razred u osnovnoj školi primjereni uzrastu učenika

\subsection{Istraživačke hipoteze}

Hipoteza -Većina nastavnih sadržaja islamske vjeronauke za prvi i drugi razred osnovne škole je primjerena uzrastu učenika. 


\subsubsection{Pomoćne hipoteze}

- Pretpostavlja se da je u udžbenicima islamske vjeronauke za prvi i drugi razred više primjerenog sadržaja u odnosu na neprimjereni sadržaj.

- Pretpostavlja se da je omjer primjerenog u odnosu na neprimjereni sadržaj na strani primjerenog sadržaja.

- Pretpostavlja se da će nastavnici, na osnovu svog iskustva, dati mišljenje da je većina sadržaja islamske vjeronauke za prvi i drugi razred primjerena uzrastu učenika.

\subsection{Uzorak}

Istraživanje je vršeno u 4 osnovne škole na Unsko-sanskom kantonu. Obuhvaćeno je 10 nastavnika koji predaju u istim školama u prvom i drugom razredu.

\subsection{Metode, tehnike $i$ instrumenti istraživanja 5.6.1. Metode istraživanja}

U ovom istraživanju kombinovano je više metoda kako bi se istraživanje obavilo obuhvatnije i kako bi dobiveni rezultati bili što vjerodostojniji. Primjenjivana je servej (Serwey) metoda, metoda teorijske analize i metoda proučavanja pedagoških podataka.

\subsubsection{Tehnike istraživanja}

Tokom istraživanja koristila se tehnika anketiranja.

\subsubsection{Instrumenti istraživanja}

Instrument koji je korišten u ovom istraživanju je anketni upitnik (upitnik za nastavnike) kojeg su popunili nastavnici koji su bili obuhvaćeni ovim istraživanjem.

\footnotetext{
7 Anketa je vršena u četiri osnovne škole Unsko-sanskog kantona ito: JU OŠ "Šturlić” iz Šturlića, JU OŠ “Tržačka Raštela” iz Trž. Raštela, JU OŠ "Liskovac" iz Liskovca i JU OŠ "Donja Vidovska" iz Donje Vidovske, kojom je uzeto mišljenje 10 nastavnika.
} 


\subsection{Metode obrade podataka}

Sistematiziranje podataka dobivenih ovim istraživanjem vršeno je slijedećim statističkim postupcima:

- Izračunavanje postotka

- Grafički prikaz

Postotak i frekvencija dobivenih rezultata prikazani su tabelama i dijagramima.

\section{Analiza i interpretacija dobivenih podataka}

Hipoteza glasi: Većina nastavnih sadržaja islamske vjeronauke za prvi razred osnovne škole je primjerena uzrastu učenika.. Kad se kaže većina, onda se misli na onaj primjereni sadržaj u udžbenicima koji prelazi $90 \%$ zastupljenosti. To nam potvrđuje teorijska naliza udžbenika i anketa provedena među nastavnicima na ovu temu.

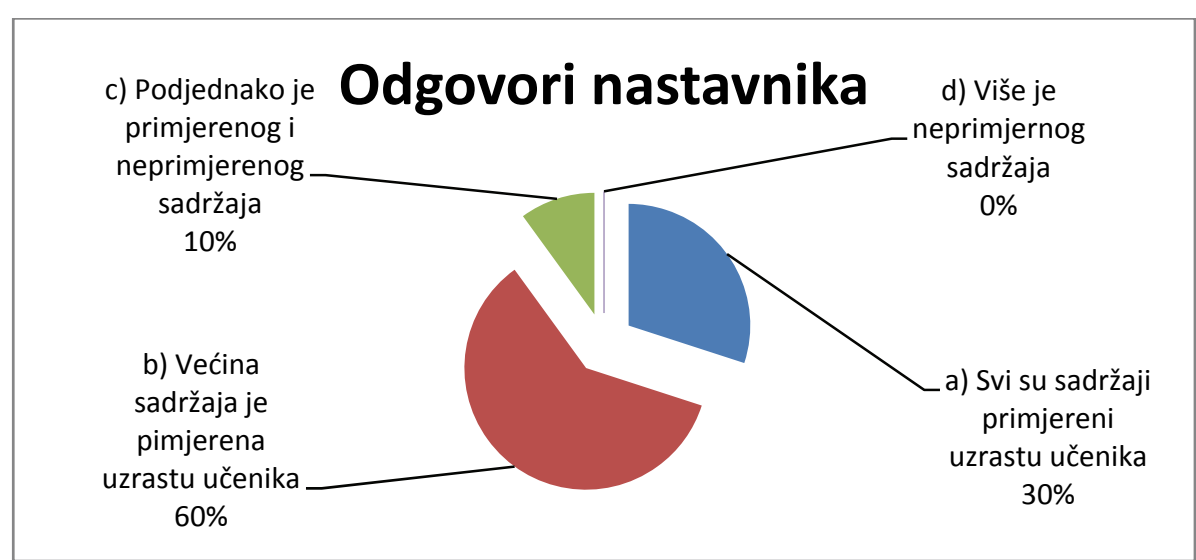

Garfikon 1.-Odgovori nastavnika na pitanje „primjerenosti nastavnih sadržaja u udžbenika islamske vjeronauke uzrastu učenika za I (prvi razred) osnovne škole“.8

U upitniku za nastavnike je bilo pitanje: $U$ udžbeniku vjeronauke za prvi razred osnovne škole, u nastavnoj jedinici " ALLAHOV POSLANIK MUHAMMED, ALEJHI-S-SELAM " na stranici 56, imamo zadatak u kojem učenici trebaju dopuniti rečenicu, a još nisu

${ }^{8}$ Anketa je vršena u četiri osnovne škole Unsko-sanskog kantona ito: JU OŠ "Šturlić" iz Šturlića, JU OŠ "Tržačka Raštela" iz Trž. Raštela, JU OŠ "Liskovac" iz Liskovca i JU OŠ "Donja Vidovska" iz Donje Vidovske, kojom je uzeto mišljenje 10 nastavnika. 
učili sva slova. Da li učenici ovog uzrasta mogu uraditi ovaj zadatak?, nastavnici odgovaraju:

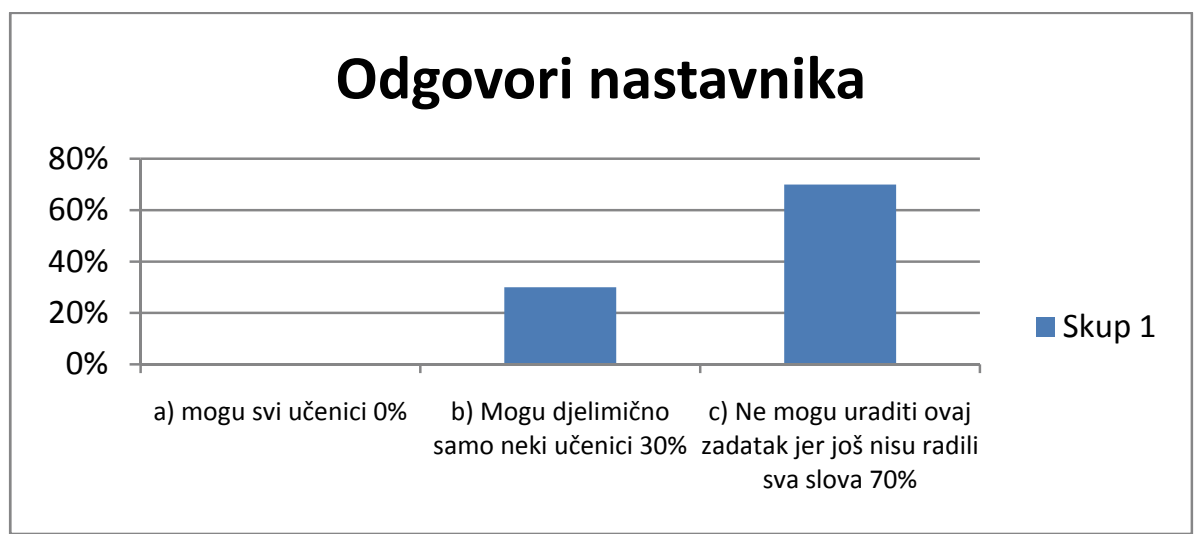

Grafikon 2. Odgovori nastavnika, da li učenici ovog uzrasta mogu uraditi zadatak na str. $56^{9}$

Kad je riječ o drugom razredu, hipoteza glasi: Većina nastavnih sadržaja islamske vjeronauke za drugi razred osnovne škole je primjerena uzrastu učenika. Kad se kaže većina, onda se misli na onaj primjereni sadržaj u udžbenicima koji prelazi $90 \%$ zastupljenosti. To nam potvrđuje teorijska analiza udžbenika i anketa provedena među nastavnicima na ovu temu.

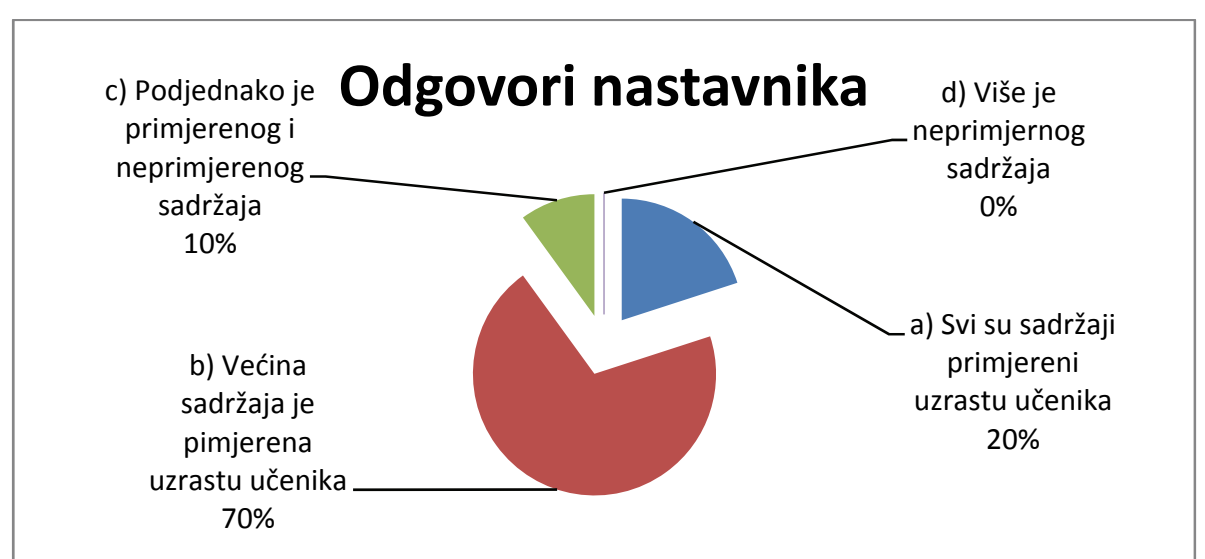

Garfikon 3.- Odgovori nastavnika na pitanje „primjerenost nastavnih sadržaja u udžbenika islamske vjeronauke uzrastu učenika za II (drugi razred) osnovne škole“. ${ }^{10}$

${ }^{9}$ Isto 
U upitniku za nastavnike je bilo pitanje, da se u udžbeniku vjeronauke za drugi razred osnovne škole, u nastavnoj jedinici "NOVA HIDŽRETSKA GODINA", na strani 100. imamo zadatak da učenici popune zadatak u kojem se traže cifre 622, 354,355, a po NPP su učili brojati do 20 . Obzirom da učenici nisu radili brojeve veće od 100 , da li mogu uraditi zdatak?

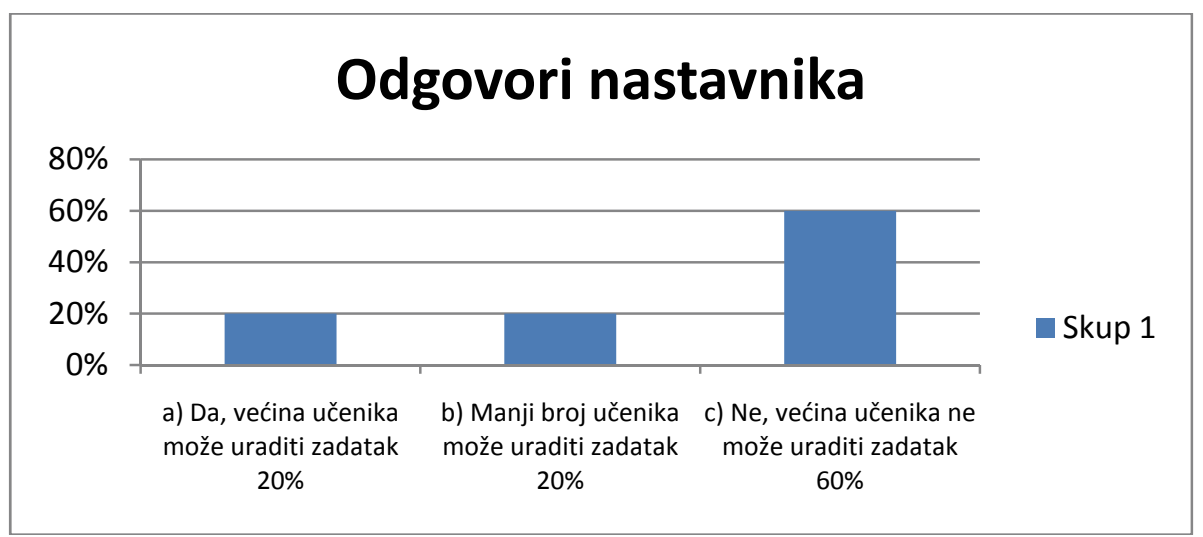

Grafikon 4. Odgovori nastavnika, obzirom da učenici nisu radili brojeve veće od 100, da li mogu uraditi zdatak na strani $100 .^{11}$

Iz gornjih grafikona vidljivo je da su nastavnici obuhvaćeni ovom anketom složni da je većina nastavnih sadržaja islamske vjeronauke za prvi i drugi razred osnovne škole primjerena uzrastu učenika.

\section{Zaključak}

Ovim se radom ukazalo na primjerenost većine nastavnih sadržaja u udžbenicima Vjeronauka I i II uzrastu učenika prvog i drugog razreda osnovne škole, dajući prijedlog korekcije i izmjene. Isto tako, ukazano je na nepostojanje korelacije s drugim predmetima, kao što su bosanski jezik ili matematika. Ovo zahtijeva veću i opsežniju analizu, što je prijedlog za dalje istraživanje. Detaljnijom analizom sadržaja, uzimajući u obzir mišljenje većeg broja nastavnika

10 Anketa je vršena u četiri osnovne škole Unsko-sanskog kantona ito: JU OŠ "Šturlić” iz Šturlića, JU OŠ "Tržačka Raštela" iz Trž. Raštela, JU OŠ "Liskovac" iz Liskovca i JU OŠ "Donja Vidovska" iz Donje Vidovske, kojom je uzeto mišljenje 10 nastavnika.

${ }^{11}$ Isto 
u praksi, nego što je uzorkovano ovim radom, kao i grafičkoislustativnog dizajna, dobio bi se uvid u neprimjerene sadržaje uzrastu učenika prvog i drugu razreda. Možda bi neki nabrojali još neke primjedbe, a neki bi za pojedine primjedbe kazali da i nisu na mjestu. Ovim bi se dobila još potpunija i preciznija slika o ovom problemu istraživanja.

Konstatuje se, da se analizom sadržaja udžbenika za prvi i drugi razred, došlo do zaključka da je omjer primjerenog sadržaja u odnosu na neprimjeren u velikoj prednosti i u omjeru 90\% naspram 10\% neprimjerenog. Udžbenik se pokazao izrazito primjeren ovom uzrastu svojim sadržajima i zadacima. Na osnovu istraživanja i analize, potvrđuje se hipoteza da je većina nastavnih sadržaja islamske vjeronauke za prvi i drugi razred osnovne škole primjeren uzrastu učenika.

Ispunilo se i očekivanje da će nastavnici na osnovu svog iskustva dati prednost primjerenom sadržaju vjeronauke u odnosu na neprimjereni.

Zaključci do kojih se došlo, jasno ukazuju da su udžbenici Vjeronauka 1 i Vjeronauka 2 osnovne škole ispunjeni primjerenim sadržajima.

Preporuka za buduće autore, iako je, ova verzija tretiranih udžbenika većinom ispunjena primjerenim nastavnim sadržajima, ovo ne bi trebali biti konačna verzija udžbenika, već treba da svaki novi udžbenik bude izložen stalnom evaluacijskom praćenju u svakom pogledu i da se mijenjaju shodno ukazanim potrebama. A što se tiče neprimjerenog sadržaja koji je istaknut, trebalo bi ga promijeniti iz udžbenika. Treba imati u vidu koje kognitivne sposobnosti imaju učenici prvog i drugog razreda osnovne škole. Mora se paziti na korelaciju s drugim predmetima kao što su bosanski jezik, matematika i drugi.

Ovaj rad bi trebao poslužiti kao poticaj za samostalno istraživanje kroz praksu o ovoj problematici i na svim ostalim uzrastima, a rezultati dobiveni ovim istraživanjem trebali bi uticati na odabir primjerenih nastavnih sadržaja tokom planiranja.

Ovo je samo mali doprinos ovoj tematici i naredna istraživanja trebala bi ponuditi veći broj prijedloga i rješenja, a to će neminovno 
otvoriti vrata za nova pitanja. Zato se nadamo da će islamski odgoj i obrazovanje, tradicionalni i savremeni, kroz islamsku vjeronauku, biti predmet mnogobrojnih budućih istraživanja $u$ cilju poboljšanja kvalitete Islamske vjeronauke.

\section{Prilog}

\section{Upitnik za nastavnike Islamske vjeronauke}

(Da bi došli do relevantnih i najpotpunijih podataka molimo Vas da bez ikakva ustručavanja zaokružite po Vama najpotpuniji odgovor $i$ ne morate se potpisivati zbog Vaše anonimnosti). U slijedećim pitanjima zaokružite ponuđene odgovore za koje smatrate da su tačni. Zaokružiti samo jedan ponuđeni odgovor. Molimo vas da odgovarate savjesno kao bi došli do što relevantnijih podataka.

1. U udžbeniku Vjeronauka 1 (vjeronauke za prvi razred osnovne škole), u nastavnoj jedinici "ALLAHOV POSLANIK MUHAMMED, ALEJHI-S-SELAM" na strani 56, imamo zadatak u kojem učenici trebaju dopuniti rečenicu, a još nisu učili sva slova.

- Da li učenici ovog uzrasta mogu uraditi ovaj zadatak:

a ) mogu svi učenici

b ) mogu djelimično ili samo neki učenici

c ) ne mogu uraditi ovaj zadatak jer još nisu radili sva slova

- U udžbeniku islamske vjeronauke za I razred osnovne škole:

a ) svi su sadržaji primjereni uzrastu učenika

b ) većina sadržaja je primjerena uzrastu učenika

c ) podjednako je primjerenog i neprimjerenog sadržaja

d ) više je neprimjerenog sadržaja

2. U udžbeniku Vjeronauka 2 (vjeronauke za drugi razred osnovne škole), u nastavnoj jedinici "NOVA HIDŽRETSKA GODINA" , na strani 100. imamo zadatak da učenici popune zadatak u kojem se traže cifre 622, 354,355, a po NPP su učili brojati do 20 . uraditi zadatak?

- Obzirom da učenici nisu radili brojeve veće od 20, da li mogu 
a ) da, većina učenika može uraditi zadatak

b ) manji broj učenika može uraditi zadatak

c ) ne, niko od učenika ne može uraditi zadatak

- U udžbeniku Vjeronauka 2 (islamske vjeronauke za II razred osnovne škole):

a ) svi su sadržaji primjereni uzrastu učenika

b ) većina sadržaja je primjerena uzrastu učenika

c ) podjednako je primjerenog i neprimjerenog sadržaja

d ) više je neprimjerenog sadržaja

Hvala vam na saradnji!

\section{Literatura:}

1. Al-Attas, S. M. N. (2010). Obrazovna filozofija i praksa. (preveli: Aida Abadžić, Behija Durmišević, Dženita Kapić, Enes Karić i Aid Smajić) Sarajevo: Bemust

2. Brajša-Žganec, A. (2003). Dijete i obitelj. Zagreb: Naklada Slap.

3. Begović, I. (2005). Vjeronauka za prvi razred osnovne škole. Sarajevo: ElKalem.

4. Buljan-Flander, G., Karlović, A. (2004). Odgajam li dobro svoje dijete-Savjeti za roditelje. Zagreb: Marko M.

5. Bognar, L., Matijević, M. (1992). Didaktika, Zagreb: Školska knjiga Zagreb.

6. Biondić, I. (1993). Integrativna pedagogija. Zagreb: Školska knjiga.

7. Cerić , M. (1998). Odgoj i obrazovanje. Takvim za 1998. Sarajevo: Rijaset islamske zajednice u $\mathrm{BiH}$.

8. Ćatić, R. (2005). Osnovi porodične pedagogije. Zenica: Pedagoški fakultet Zenica.

9. Ćatić, R. (2003). Osnovi didaktike. Zenica: Pedagoški fakultet Zenica.

10. Ćatić, R., Stevanović, M. (2003). Pedagogija. Zenica: Dom štampe.

11. Grupa autora. (2004). Školska pedagogija (izbor tekstova). Bihać: IPA Bihać.

12. Hwang, P., Nilson, B. (2000). Razvojna psihologija. Sarajevo: Filozofski fakultet.

13. Mandić, P. (1975). Saradnja porodice i škole. Sarajevo: Svjetlost-Sarajevo.

14. Malić, J., i Mužić, V. (1984). Pedagogija. Zagreb: Školska knjiga 
15. Mužić, V. (1999). Uvod u metodologiju istraživanja odgoja i obrazovanja. Zagreb: Educa.

16. Ramić, O. (2005). Razvojna psihologija ( skripta ). Bihać; IPA.

17. Rosić, V. ( 2005). Odgoj-obitelj-škola. Rijeka: Žagar.

18. Rot, N. (1983). Opšta psihologija. Beograd: Zavod za udžbenike i nastavna sredstva.

19. Spahić, M. (2002). Učenje islama. Zenica: Biblioteka Kaf.

20. Tinjak, M. (2006). Vjeronauka za drugi razred osnovne škole. Sarajevo: ElKalem.

21. Veladžić, N. (2010). Metodologija društvenih nauka. (Skripta za studente). Bihać: Pravni fakultet Bihać.

22. Vilotijević, M. (2001). Didaktika 3. Sarajevo: BH most.

23. Vukasović, A. (1999). Pedagogija. Zagreb: Hrvatski katolički zbor „MI“.

24. Više autora. (1963). Enciklopedijski rječnik pedagogije. Zagreb: Matica Hrvatska.

25. Zarevski, P. (1997). Psihologija pamćenja i učenja. Jastrebarsko: Naklada slap. 
Nisfet Kovacevic, prof.

SUITABILITY OF THE TEACHING CONTENT OF THE "ISLAMIC RELIGIOUS EDUCATION" FOR THE PUPILS IN THE FIRST AND THE SECOND GRADES OF THE PRIMARY SCHOOLS

\section{SUMMARY}

Continuous efforts of participants of the teaching process is to adequately present and deliver the material which is provided by the Curriculum. The textbooks are indispensable tool in the realization of this task. Therefore, the aim of this study was to review the appropriate and inappropriate content, for the pupils which can be found the in religious education textbooks I and II for elementary school, and to examine the dominance of one over the other.

The paper has, through theoretical analysis, survey research, and collecting and processing of the data, confirmed the hypothesis that we can find a significant dominance of the appropriate content over the inadequate in the both textbooks.

Also, examples of inappropriate teaching content to the pupils' age are particularly stressed and the research itself has pointed out the need for greater intersubject correlation during of the planning process. Therefore this work is a stimulus to further research in order to provide better quality of textbooks, planning and implementation of the teaching process.

Keywords: Islamic religious education, Curriculum, student, religious education textbooks, school materials 


\section{الأستاذ نسفت كوفاتشيفيتش}

\section{ملاءمة مقرر مادة التربية الإسلامية لعمر تلاميذ الصف الأول والثاني الابتدائي}

\section{خلاصية البحث}

يسعى المشاركون في العملية التعليمية بشكل دؤوب لعرض وتوصيل مثالي

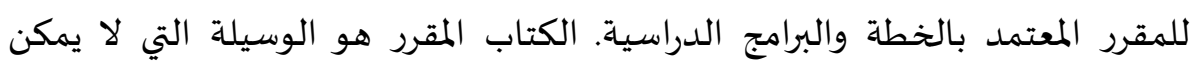
تجاهلها في تنفيذ تلك المهمة. لذا كان الهدف من هذا البحث هو التفات إلى مقررات

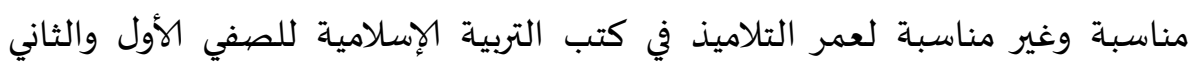
الابتدائي، ولفحص هيمنة المناسب وغير مناسبة لهمبل غيره.

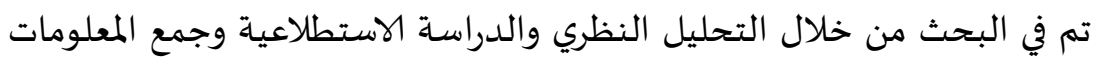
وتجهيزها إثباتُ فرضية هيمنة واضحة للمقررات المناسبة على غير المناسبة في كلا

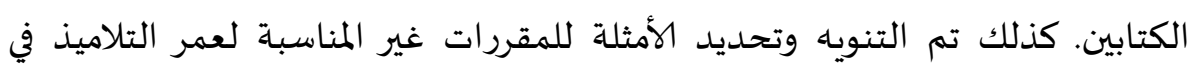

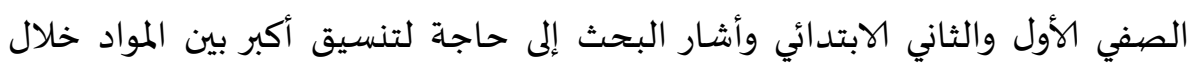

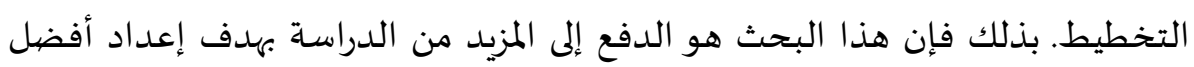

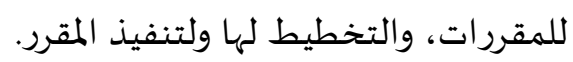

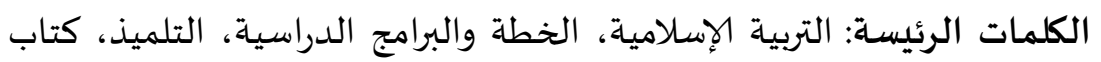

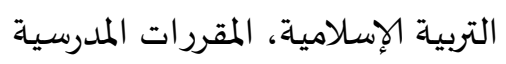

